\title{
Kemampuan Pemecahan Masalah Matematika Mahasiswa Teknik Sipil Ditinjau dari Gaya Kognitif
}

\section{Ahmat Wakit ${ }^{1}$ and Nor Hidayati ${ }^{2}$}

\author{
1,2Universitas Islam Nahdlatul Ulama Jepara
}

Corresponding Author: ahmatwakit@unisnu.ac.id',norhida@unisnu.ac.id²

DOI: http://dx.doi.org/10.15294/kreano.v1 1i1.21047

Received: August 13 2019; Accepted: May 13 2020; Published: June 12020

\begin{abstract}
Abstrak
Penelitian ini bertujuan untuk menganalisis kemampuan pemecahan masalah matematika mahasiswa Teknik Sipil ditinjau dari gaya kognitif. Penelitian merupakan penelitian deskriptif kualitatif. Sebanyak 26 subjek kelas GA ditentukan gaya kognitifnya menggunakan Group Embedded Figure Test (GEFT) untuk mengelompokkan subjek Field Dependent (FD), Field Intermediate (FDI), dan Field Independent (FI). Setiap kategori gaya kognitif diambil 2 mahasiswa dengan skor rendah dan tinggi yang dijadikan subjek penelitian. Hasil pemecahan masalah mahasiswa menunjukkan bahwa subjek FD Lemah belum mampu memenuhi semua indikator pemecahan masalah dan membutuhkan bimbingan lebih dalam menyelesaikan permasahalan yang dihadapi. Subjek FD Kuat mengalami kendala dalam menggunakan pengetahuan konsep dan menerapkan berbagai strategi yang tepat untuk memecahkan masalah, dan merefleksikan proses pemecahan masalah menggunakan langkah Polya. Kemampuan pemecahan masalah subjek FDI Lemah dan FDI Kuat tergolong baik, namun masih belum mampu melakukan pengecekan kembali. Subjek FI Lemah dan FI Kuat memiliki kemampuan pemecahan masalah yang baik. Seluruh indikator pemecahan masalah terpenuhi.
\end{abstract}

Kata Kunci: gaya kognitif; kemampuan menyelesaikan masalah

\begin{abstract}
This research aims to analyze the mathematical problem solving abilities of Civil Engineering students in terms of cognitive style. The research is a qualitative descriptive study. A total of $26 \mathrm{GA}$ class subjects were determined by their cognitive style using the Group Embedded Figure Test (GEFT) to group Field Dependent (FD), Field Intermediate (FDI), and Independent Field (FI) subjects. Each category of cognitive style was taken by 2 students with low and high scores which were used as research subjects. The results of student problem solving show that the subject of Weak FD has not been able to meet all the indicators of problem solving and requires more guidance in solving the problem at hand. The subject of Strong FD encountered problems in using concept knowledge and implementing various appropriate strategies to solve problems, and reflecting the problem solving process using Polya's steps. The problem solving ability of the subject FDIL weak and strong FDI is quite good, but still not able to check again. Weak FIL and Strong Fl subjects have good problem solving skills. All indicators of problem solving are met.
\end{abstract}

Keywords: cognitive style;problem solving skill 


\section{PENDAHULUAN}

Sesuai Peraturan Menteri Riset, Teknologi, dan Pendidikan Tinggi Republik Indonesia Nomor 44 Tahun 2015, lulusan perguruan tinggi harus menguasai capaian sikap, pengetahuan, dan keterampilan (keterampilan umum dan keterampilan khusus) yang secara jelas dirumuskan dalam capaian pembelajaran lulusan. Sehingga pembelajaran yang dilakukan harus mengacu pada pencapaian capaian-capaian tersebut. Salah satu kemampuan yang penting dalam proses berpikir matematika adalah kemampuan pemecahan masalah matematika. Pendidikan harus lebih fokus pada bidang keterampilan tertentu seperti keterampilan pemecahan masalah, keterampilan berkolaborasi dan lain-lain (Häkkinen, 2017). Oleh karena itu diperlukan pengajaran yang dapat memacu mahasiswa dalam meningkatkan kemampuan memecahkan masalah matematika. Kemampuan pemecahan masalah matematika mahasiswa Teknik Sipil Fakultas Sains dan Teknologi Universitas Islam Nahdlatul Ulama (UNISNU) Jepara tergolong rendah. Hal ini terlihat dari hasil tes awal menunjukkan rata-rata nilai kemampuan menalar matematika adalah 54 dan kemampuan memecahkan masalah masalah matematika 59. Rendahnya kemampuan pemecahan masalah matematika ini disebabkan adanya beberapa kesalahan, seperti tidak dapat memahami masalah dan tidak dapat merancang permasalahan.

Hasil penyelesaian mahasiswa pada penelitian awal menunjukkan bahwa 1) mahasiswa tidak bisa memahami permasalahan sehingga mahasiswa tidak bisa merencanakan dan menyelesaikan permasalahan dengan benar; 2) mahasiswa mengalami kesulitan untuk merencanakan penyelesaian masalah sehingga mahasiswa tidak mampu menyelesaikan permasalahan dengan benar; 3) kesalahan mahasiswa disebabkan oleh ketidakmampuan mahasiswa dalam menerapkan empat tahap penyelesaian masalah. Jika dilihat dari tahapan pemecahan masalah matematika, pada tahap pertama memahami masalah, mahasiswa kurang cermat dalam hal memahami jenis soal tes sehingga tidak faham informasi dari soal. Tahap kedua merencanakan penyelesai- an, mahasiswa tidak dapat mengumpulkan informasi dan menerapkan konsep matematika. Tahap ketiga menyelesaikan masalah, mahasiswa tidak dapat menyelesaikan masalah karena tidak mengerti apa yang dilakukan. Tahap keempat memeriksa kembali, mahasiswa tidak mengoreksi kembali jawaban yang sudah ditulis sehingga tidak mengetahui bahwa jawaban benar atau salah.

Pemilihan strategi/model/metode pembelajaran yang efektif sangat menentukan kualitas pemahaman atau target pembelajaran. Guru dapat memotivasi siswa agar lebih tertarik mempelajari matematika dengan mengaitkan materi yang dipelajari dengan permasalahan dalam kehidupan sehari-hari. (Karatas \& Baki, 2013) menjelaskan bahwa problem based learning (PBL) dapat meningkatkan hasil belajar seperti pemahaman konsep dan kemampuan memecahkan masalah secara signifikan dan menurut (Jaisook, Chidmongkol, \& Thongthew, 2013) PBL secara efektif digunakan dalam pembelajaran matematika dan dapat meningkatkan pemahaman dan kemampuan siswa untuk menerapkan konsep matematika dalam kehidupan seharihari. (Tiffany, Surya, Panjaitan, \& Syahputra, 2017) menyatakan bahwa kemampuan pemecahan masalah adalah strategi atau cara siswa memecahkan masalah dengan menggunakan reaksi sistematis. Proses PBL yang lebih luas dapat menciptakan peluang untuk mengembangkan pengetahuan, sikap dan kemampuan yang bermakna terkait dengan pembelajaran bersama, sehingga dapat membangun pengetahuan kolaboratif yang efektif, membantu siswa untuk membuat hubungan eksplisit antara sikap terhadap kolaborasi dan mencapai hasil pembelajaran, dan mengidentifikasi spesifik kemampuan kolaboratif yang dibutuhkan oleh siswa, dan diperoleh melalui hasil kolaborasi kelompok (Murray-harvey, Pourshafie, \& Reyes, 2013).

Kegiatan pokok pada model ini adalah memecahkan persoalan melalui rangkaian kegiatan kelompok berdasarkan permasalahan sehari-hari sehingga mahasiswa menjadi aktif dalam pembelajaran. Menurut Davidson \& Major (2014) PBL mempunyai dampak positif pada aktifitas dan kerjasama siswa. Fokus 
utama pembelajaran ini adalah pembelajaran yang menekankan pada aktivitas siswa. Servant-Miklos (2018) menambahkan bahwa jika guru ingin menggunakan $\mathrm{PBL}$, maka harus memberikan perhatian khusus pada fase diskusi dan penggunaan beragam permasalahan. Ari \& Katranci (2014) menambahkan bahwa PBL dapat digunakan untuk meningkatkan kemampuan berpikir segaca signifikan dan meningkatkan keterampilan pemecahan masalah, tetapi persiapan dan praktik metode ini memakan waktu. Disisi lain, cara siswa dalam menerima dan mengolah informasi (gaya kognitif) juga mempengaruhi strategi siswa dalam menyelesaikan masalah matematika (Winarso \& Dewi, 2017). Idris dalam Ulya (2015) membagi gaya kognitif menjadi 3 tipe yaitu Field Dependent (FD), Field Intermediate (FDI), dan Field Independent (FI). MenurutYousefi (2011) bahwa karakter FD cenderung bekerja dengan motivasi eksternal, yaitu mencari bimbingan dan petunjuk dari orang lain, sedangkan karakter FDI cenderung memiliki kemampuan seperti FD atau FI karena FDI terletak di antara keduanya. Sedangkan karakter FI memandang persoalan secara analitis, mampu menganalisis dan mengisolasi rincian yang relevan, mendeteksi pola, dan mengevaluasi secara kritis suatu persoalan.

Keberhasilan pembelajaran juga diikuti dengan ketersediaan dan kesesuaian instrumen pembelajaran yang berkualitas. Sehingga belum tersedianya perangkat pembelajaran dengan PBL pada kelas ini, juga merupakan faktor yang membuat mahasiswa tidak dapat memaparkan pengetahuannya untuk menentukan penyelesaian dari masalah yang dihadapi. Oleh karena itu perlu adanya pelaksanan pembelajaran dengan PBL berbasis KKNI diharapkan dapat meningkatkan kemampuan menalar mahasiswa dan kemampuan memecahkan masalah matematika.

\section{METODE}

Penelitian ini termasuk jenis penelitian kualitatif menggunakan pendekatan deskriptif kualitatif. Penelitian ini memiliki 2 tahap kegiatan yaitu tahap pra lapangan dan tahap pekerjaan lapangan.

Tahap pekerjaan lapangan diawali dengan penentuan gaya kognitif mahasiswa, se- lanjutnya diadakan kegiatan pembelajaran untuk membiasakan mahasiswa dengan soal tipe Pemecahan Masalah Matematika (PMM). Dilanjutkan dengan menganalisis data kemampuan penalaran dan kemampuan pemecahan masalah matematika. Adapun alur penelitian terurai pada Gambar 1.

Subjek penelitian adalah mahasiswa Teknik Sipil UNISNU Jepara Kelas GA yang mengambail mata kuliah Matematika II. Penetapan subjek mengacu pada hasil tes gaya kognitif. Subjek dipilih dengan melihat nilai hasil dari tes GEFT yaitu 2 mahasiswa dari masing-masing gaya kognitif. Pengambilan 2 mahasiswa tersebut mengacu pada nilai yang diperoleh setelah tes GEFT. Mahasiswa yang dipilih sebagai subjek penelitian adalah 1 mahasiswa yang memiliki nilai terendah dan 1 mahasiswa yang memiliki nilai tertinggi dari masing-masing gaya kognitif. Data diperoleh dari hasil tes, lembar pekerjaan mahasiswa, hasil wawancara, dan dokumen lain dalam materi integral.

Teknik pengumpulan data pada penelitian ini menggunakan teknik tes dan teknik non tes. Teknik tes menghasilkan data hasil pekerjaan mahasiswa dalam menyelesaikan pemecahan masalah, sedangkan teknik non tes menggunakan metode wawancara untuk memperoleh kredibilitas data.

Sosal tes PMM berbentuk tes tertulis, hasil dari tes ini dianalisis untuk mengetahui tentang kemampuan pemecahan masalah matematika mahasiswa dalam bentuk soal yang diberikan dan menyelesaikan masalah matematika.

Wawancara dilaksanakan setelah mahasiswa mengerjakan tes tulis. Wawancara dilaksanakan untuk memperoleh keabsahan hasil dari penyelesaian mahasiswa dalam menyelesaikan tes PMM. Gambar 2, menyajikan tahapan-tahapan dalam pengumpulan data.

Teknik yang digunakan dalam menentukan keabsahan data dalam penelitian ini terdiri dari empat tahapan, yaitu (1) kredibilitas (credibility) data dengan teknik triangulasi data dengan menggunakan cara triangulasi teknik, yaitu membandingkan hasil atau mengecek ulang derajat kepercayaan dengan teknik yang berbeda, yaitu melalui tes PMM dan wawancara terhadap informan/subjek; 


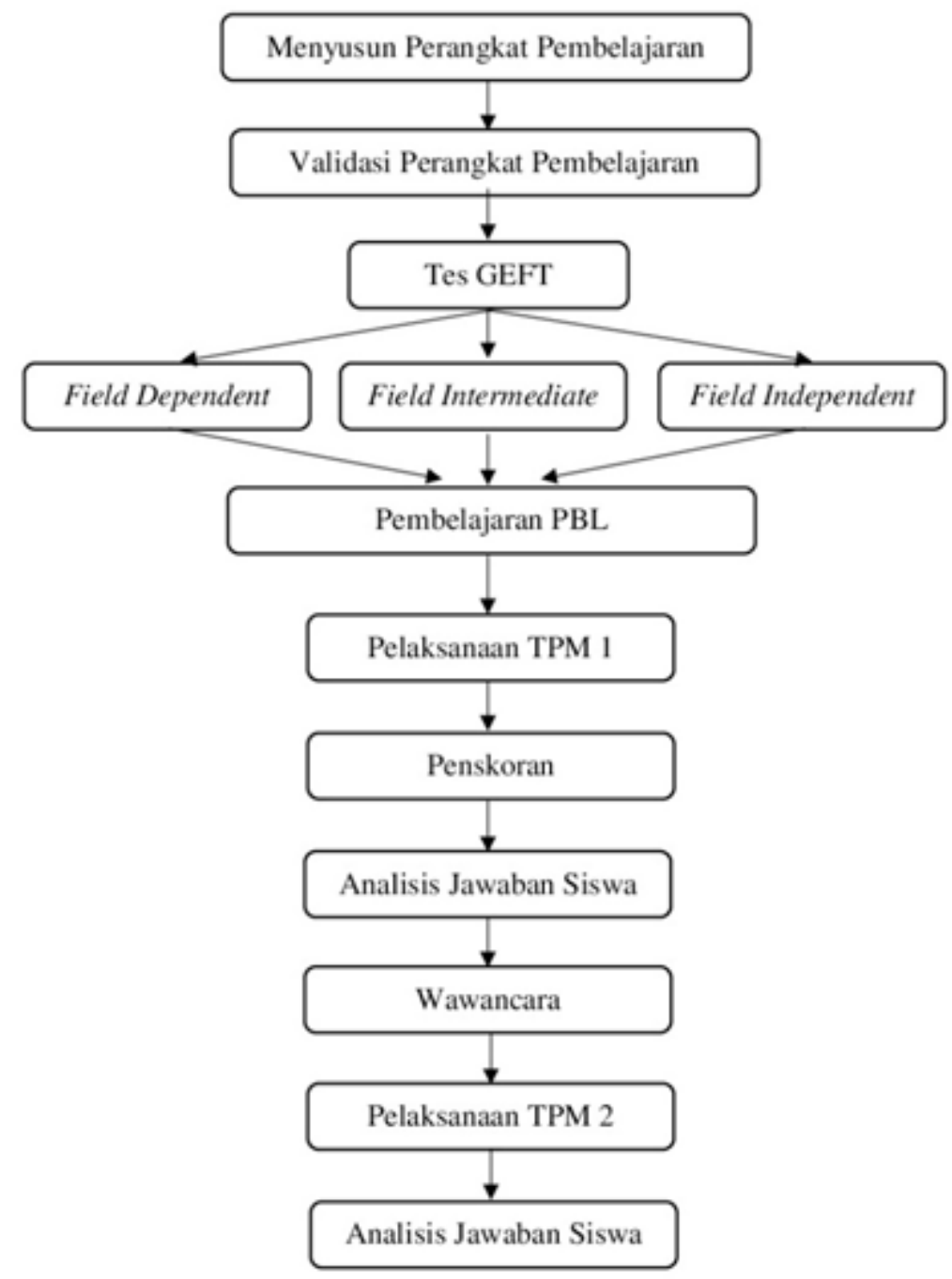

Gambar 1. Alur Penelitian

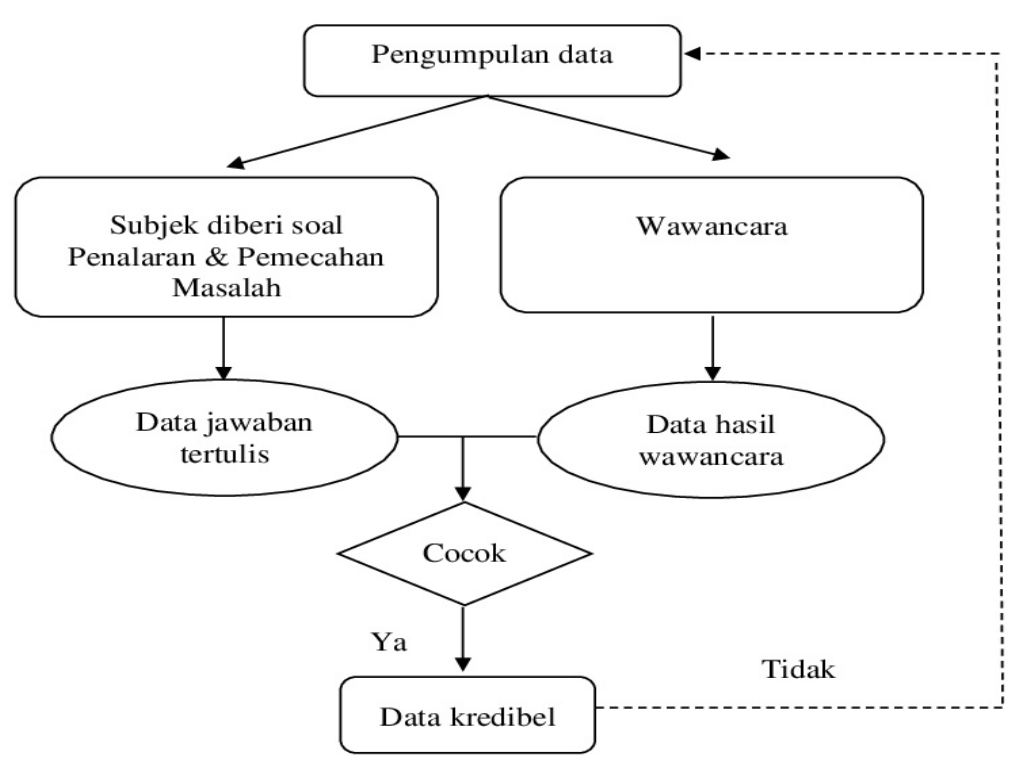

Gambar 2. Alur Teknik Pengumpulan Data Penelitian 
(2) Keteralihan (transferability) data diperoleh dengan cara mendeskripsikan kemampuan pemecahan masalah matematika mahasiswa secara rinci dan sistematis; (3) Pada penelitian ini, kebergantungan (dependability) data ditempuh dengan cara mengambil 2 subjek untuk setiap gaya kognitif; (4) Kepastian (confirmability) data diperoleh dengan cara menghindari subjektivitas saat pengambilan data dengan cara membuat pedoman wawancara dan membuat pedoman penilaian tes.

\section{HASIL DAN PEMBAHASAN}

Gaya kognitif mahasiswa kelas GA diklasifikasikan menjadi gaya kognitif FD, FDI, dan FI. Berikut klasifikasi subjek disajikan pada Tabel 1.

Tabel 1. Klasifikasi Gaya Kognitif Subjek Penelitian

\begin{tabular}{cc}
\hline Kategori & Jumlah siswa \\
\hline FD & 11 \\
FDI & 9 \\
FI & 6 \\
\hline
\end{tabular}

Dari data tersebut dapat ditunjukkan bahwa mahasiswa yang masuk ke dalam gaya kognitif FD lebih banyak jika dibandingkan mahasiswa yang tergolong gaya kognitif FDI dan FI. Jumlah mahasiswa yang masuk ke dalam kategori FDI tidak berbeda jauh dengan mahasiswa Fl, hanya selisih 3 mahasiswa. Selisih jumlah mahasiswa FD dengan FDI lebih banyak jika dibandingkan selisih jumlah FDI dengan FI. Hal ini disebabkan oleh faktor rentang skala skor GEFT.

Hasil klasifikasi gaya kognitif mahasiswa ini digunakan sebagai dasar untuk penyusunan kelompok diskusi untuk setiap pertemuan. Setiap kelompok yang dibentuk terdiri atas mahasiswa yang berasal dari gaya kognitif FD, FDI, dan Fl, sehingga kelompok yang dibuat adalah kelompok heterogen dari berbagai gaya kognitif. Setelah penentuan subjek berdasarkan gaya kognitif, subjek diberi pembelajaran dengan soal pemecahan masalah. Pembelajaran PBL dalam penelitian ini digunakan untuk memfasilitasi mahasiswa mengenal soal pemecahan masalah yang harus diselesaikan menggunakan langkah Polya.

Data kemampuan mahasiswa dalam pemecahan masalah adalah data kemampuan mahasiswa dalam menyelesaikan soal pemecahan masalah matematika dengan mengikuti langkah Polya. Soal yang digunakan adalah soal non-rutin. Soal harus diselesaikan menggunakan langkah Polya yang harus memuat 4 aspek, yaitu (1) memahami masalah, (2) menyusun rencana pemecahan masalah, (3) melaksanakan rencana pemecahan masalah, dan (4) mengecek kembali hasil pemecahan masalah (Pólya \& Conway, 1910).

Subjek FDL adalah subjek yang memiliki skor GEFT terendah dalam kategori FD Subjek FDL tidak dapat memahami masalah yang diberikan dengan baik. Berdasarkan jawaban subjek FDL, bahwa subjek dapat menuliskan sebagian informasi dari hal yang diketahui tetapi tidak lengkap. Beberapa informasi penting dari suatu permasalahan tidak dituliskan. Selain itu subjek FDL dapat menuliskan hal yang ditanyakan. Pada saat wawancara dilakukan, subjek FDL dapat menyebutkan hal yang diketahui dengan jelas tetapi tidak lengkap. Subjek FDL dapat menyebutkan hal yang ditanyakan sesuai kalimat yang terdapat pada soal.

Subjek FDK adalah subjek yang memiliki skor GEFT tertinggi dalam kategori FD, subjek FDK memiliki kemampuan yang cukup baik dalam hal memahami masalah. Namun subjek FDK belum dapat menyusun rencana dan melaksanakan rencana pemecahan masalah dengan baik dan belum mampu mengecek kembali hasil pemecahan masalah yang dilakukan. Subjek FDK dapat membangun pengetahuan matematika baru melalui pemecahan masalah, karena mampu memahami informasi yang terdapat pada soal dengan baik. Subjek FDK juga mampu memanfaatkan informasi dari suatu permasalahan. Subjek mampu menuliskan hal yang diketahui, hal yang ditanyakan. Serta subjek FDK mampu memanfaatkan informasi dari soal. Hal ini dapat dilihat dari strategi yang disusun untuk memecahkan masalah. Subjek dapat memperkirakan strategi pemecahan masalah dengan tepat dan dapat menuliskan strategi pemecahan masalah dengan lengkap dan sistematis tetapi tidak menuliskan rumus yang akan digunakan.

Subjek tidak mampu menggunakan 
pengetahuan prasyarat untuk menyelesaikan permasalahan. Subjek mampu menghubungkan pengetahuan matematika dengan kehidupan sehari-hari dengan benar. Subjek memahami bahwa harus menyelesaikan permasalahan dengan mencari luas permukaan dari bangun tersebut.Subjek FDK tidak mampu menerapkan berbagai strategi yang tepat untuk memecahkan masalah. Hal ini disebabkan oleh subjek tidak mempunyai konsep pengetahuan prasyarat yang matang. Selain itu subjek kurang teliti dalam perhitungan sehingga penyelesaian selanjutnya tidak dapat terselesaikan dengan baik. Subjek belum mampu merefleksikan proses pemecahan masalah dengan baik. Hal ini dibuktikan dengan proses pemecahan masalah dengan langkah Polya yang dilakukan belum sempurna. Hal ini sejalan dengan penelitian sebelumnya (Mulyati, 2016; Karaçam \& Digilli Baran, 2015; dan Susanto, 2013) yang menjelaskan bahwa subjek FD dapat menerima/memahami masalah dengan membaca dan memahami maksud soal, mengidentifikasi unsur-unsur penting dalam soal meskipun kurang lengkap. Prabawa dan Zaenuri (2017) juga menambahkan bahwa Siswa FDK mampu memahami masalah dan merencanakan rencana penyelesaian, namun kurang mampu melaksanakan rencana penyelesaian dan memeriksa kembali.

Subjek FDIL adalah subjek yang memiliki skor GEFT terendah dalam kategori FDI. Subjek FDIL memiliki kemampuan yang cukup baik dalam hal memahami masalah, menyusun rencana pemecahan masalah, dan melaksanakan rencana pemecahan masalah. Namun subjek ini masih menemui kendala dalam mengecek kembali hasil pemecahan masalah matematika. Subjek FDIL dapat membangun pengetahuan matematika baru melalui pemecahan masalah, karena mampu memahami informasi yang terdapat pada soal dengan baik. Subjek FDIL juga mampu memanfaatkan informasi dari suatu permasalahan. Subjek mampu menuliskan hal yang diketahui, dan hal yang ditanyakan serta dapat memanfaatkan informasi dari soal. Hal ini dapat dilihat dari strategi yang disusun subjek untuk memecahkan masalah. Subjek dapat memperkirakan strategi pemecahan masalah dengan tepat. Subjek dapat menuliskan stra- tegi pemecahan masalah dengan lengkap dan sistematis disertai dengan rumus yang akan digunakan dengan lengkap. Subjek mampu memanfaatkan pengetahuan prasyarat untuk menyelesaikan permasalahan. Subjek FDIL mampu menerapkan strategi yang tepat untuk memecahkan masalah. Subjek mempunyai konsep pengetahuan dan pengetahuan prasyarat yang baik. Namun subjek tidak mampu menyelesaikan masalah dengan langkah yang berbeda-beda. Subjek mampu merefleksikan proses pemecahan masalah dengan cukup baik. Hal ini dibuktikan dengan proses pemecahan masalah dengan langkah Polya yang dilakukan subjek FDIL. Subjek hanya tidak mampu dalam melakukan pengecekan kembali hasil pemecahan masalah.

Subjek FDIK adalah subjek yang memiliki skor GEFT tertinggi dalam kategori FDI. Subjek FDIK memiliki kemampuan yang cukup baik dalam hal memahami masalah, menyusun rencana pemecahan masalah, dan melaksanakan rencana pemecahan masalah. Titik pada tahap mengecek kembali subjek FDIK mulai bergerak menjauh dari titik o. Subjek berusaha mengecek kembali hasil pemecahan masalah. Namun subjek mengalami kesulitan dalam membuat alternatif jawaban dan kurang teliti dalam melakukan pengecekan hasil.

Subjek FDIK dapat membangun pengetahuan matematika baru melalui pemecahan masalah. Subjek mampu memahami informasi yang terdapat pada soal dengan baik. Subjek FDIK mampu memanfaatkan semua informasi dari suatu permasalahan. Subjek mampu menuliskan hal yang diketahui dan hal yang ditanyakan dengan lengkap dan benar. Subjek dapat memanfaatkan informasi dari soal yang ditunjukkan dengan penyusunan strategi untuk memecahkan masalah. Subjek dapat memperkirakan strategi pemecahan masalah dengan tepat. Subjek dapat menuliskan strategi pemecahan masalah dengan lengkap dan sistematis disertai dengan rumus yang akan digunakan dengan lengkap. Hal ini menguatkan temuan riset sebelumya (Ulya et al, 2014).

Subjek FIL adalah subjek yang memiliki skor GEFT terendah dalam kategori FI. Subjek FIL memiliki kemampuan yang cukup baik dalam hal memahami masalah, menyusun ren- 
cana pemecahan masalah, dan melaksanakan rencana pemecahan masalah. Subjek mampu mengecek kembali hasil pemecahan masalah tetapi hanya beberapa persoalan. Subjek mengalami kesulitan dalam membuat alternatif jawaban dari suatu permasalahan.

Subjek FIL dapat membangun pengetahuan matematika baru melalui pemecahan masalah. Subjek mampu memahami informasi yang terdapat pada soal dengan baik. Subjek mampu memanfaatkan semua informasi dari suatu permasalahan. Subjek mampu menuliskan hal yang diketahui dengan lengkap dan benar serta menuliskan hal yang ditanyakan dengan jelas. Subjek dapat menggambar sketsa dengan lengkap dan tepat. Subjek dapat memanfaatkan informasi dari soal yang ditunjukkan dengan penyusunan strategi untuk memecahkan masalah. Subjek dapat memperkirakan strategi pemecahan masalah dengan tepat. Subjek dapat menuliskan strategi pemecahan masalah dengan lengkap dan sistematis disertai dengan rumus yang akan digunakan dengan lengkap.

Subjek FIL mampu menerapkan strategi yang tepat untuk memecahkan masalah. Subjek mempunyai konsep pengetahuan dan pengetahuan prasyarat yang baik. Namun subjek tidak mampu menyelesaikan masalah dengan langkah yang berbeda-beda. Subjek mampu merefleksikan proses pemecahan masalah dengan baik. Hal ini dibuktikan dengan proses pemecahan masalah dengan langkah Polya yang dilakukan subjek FIL. Subjek mampu melakukan proses pemecahan masalah mengikuti langkah Polya dengan baik. Pada tahap mengecek kembali, subjek melakukan pengecekan kembali hasil pemecahan masalah pada beberapa permasalahan tetapi tidak dapat membuat alternatif jawaban. Temuan ini hampir serupa dengan dampak pembelajaran kooperatif terhadap hasil belajar siswa (Vega-vaca dan Hederich-Martnez, 2015).

Subjek FIK adalah subjek yang memiliki skor GEFT tertinggi dalam kategori FI. Subjek FIK memiliki kemampuan yang cukup baik dalam hal memahami masalah, menyusun rencana pemecahan masalah, dan melaksanakan rencana pemecahan masalah. Subjek dapat melakukan pengecekan kembali hasil akhir dari pemecahan masalah untuk beberapa permasalahan tetapi tidak mampu membuat alternatif jawaban dari suatu permasalahan. Hal ini menguatkan hasil analisis kemampuan berpikir kritis berdasarkan gaya kognitif siswanya (Agoestanto dan Sukestiyarno, 2017). Berpikir kritis dan Kemampuan pemecahan masalah cukup dekat hubungannya (Tiwari et $a l, 2006$; Widyatiningtyas et al, 2015).

Subjek FIK dapat membangun pengetahuan matematika baru melalui pemecahan masalah. Subjek mampu memahami informasi yang terdapat pada soal dengan baik. Subjek mampu memanfaatkan semua informasi dari suatu permasalahan. Subjek mampu menuliskan hal yang diketahui dengan lengkap dan benar serta menuliskan hal yang ditanyakan dengan jelas. Subjek dapat menggambar sketsa dengan lengkap dan tepat. Subjek dapat memanfaatkan informasi dari soal yang ditunjukkan dengan penyusunan strategi untuk memecahkan masalah. Subjek dapat memperkirakan strategi pemecahan masalah dengan tepat. Subjek dapat menuliskan strategi pemecahan masalah dengan lengkap disertai dengan rumus yang akan digunakan dengan lengkap. Subjek mampu memanfaatkan pengetahuan prasyarat untuk menyelesaikan permasalahan.

Subjek FIK mampu menerapkan strategi yang tepat untuk memecahkan masalah. Bahkan subjek FIK menggunakan suatu strategi pemecahan masalah yang belum pernah diajarkan di sekolah. Subjek mempunyai konsep pengetahuan dan pengetahuan prasyarat yang baik. Namun subjek tidak mampu menyelesaikan masalah dengan langkah yang berbeda-beda. Subjek mampu merefleksikan proses pemecahan masalah dengan baik meskipun belum sempurna. Hal ini dibuktikan dengan proses pemecahan masalah dengan langkah Polya yang dilakukan. Subjek dapat melakukan dengan baik untuk tahap 1 sampai dengan 3, tetapi pada tahap akhir Polya subjek tidak dapat membuat alternatif jawaban lain untuk suatu permasalahan. Hasil ini selaras dengan penelitian Ulya (2015) bahwa terdapat hubungan yang positif antara kemampuan pemecahan masalah matematika dengan gaya kognitif. Serta penelitian Prabawa \& Zaenuri (2017) yang menunjukkan perbedaan kemampuan pemecahan masalah 
matematika antara kelompok FI dan FD.

\section{SIMPULAN}

Berdasarkan analisis hasil penelitian dapat disimpulkan bahwa : (1) Kemampuan pemecahan masalah subjek FDL dan FDK memiliki beberapa perbedaan. Perbedaan itu diantaranya terletak pada indikator membangun pengetahuan matematika baru melalui pemecahan masalah. Subjek FD membutuhkan banyak bimbingan untuk memahami masalah. Subjek FD tidak dapat memanfaatkan pengetahuan prasyarat untuk memecahkan masalah dalam berbagai konteks yang berkaitan dengan matematika. Namun subjek mampu menghubungkan pengetahuan matematika dengan kehidupan sehari-hari. Subjek tidak mampu menerapkan berbagai strategi yang tepat untuk memecahkan masalah. Subjek FD belum mampu merefleksikan proses pemecahan masalah menggunakan langkah Polya dengan baik; (2) Pada tahap memahami masalah kedua subjek FD memiliki perbedaan. Subjek FDL dapat menuliskan hal yang diketahui pada permasalahan dengan jelas tetapi tidak lengkap. Subjek ini mampu menuliskan hal yang ditanyakan pada soal tetapi tidak mampu menyebutkan secara jelas maksud dari hal yang ditanyakan dari soal. Subjek juga tidak dapat menggambarkan sketsa dari permasalahan dengan benar. Sedangkan subjek FDK dapat menuliskan hal yang diketahui pada permasalahan dengan jelas dan lengkap. Subjek ini mampu menuliskan hal yang ditanyakan pada soal dan dapat membuat sketsa dari permasalahan dengan benar; (3) Pada tahap menyusun rencana pemecahan masalah kedua subjek FD juga memiliki perbedaan. Subjek FDL tidak dapat menyusun rencana pemecahan masalah dengan benar, sedangkan subjek FDK dapat menyusun rencana pemecahan masalah dengan benar. Namun pada tahap ini kedua subjek memiliki persamaan, yaitu tidak dapat menuliskan rumus yang akan digunakan dengan benar. Hal ini menunjukkan bahwa individu FD masih belum dapat menggunakan informasi untuk merencanakan langkah-langkah penyelesaian sehingga mengalami kesulitan dalam menentukan langkah dan perhitungan selanjutnya; dan (4) Pada tahap melaksanakan rencana pemecahan masalah kedua subjek FD tidak dapat menjawab masalah dengan benar karena tidak dapat membuat rencana pemecahan masalah dengan benar. Oleh karena masalah tidak terselesaikan, maka subjek tidak dapat mengkomunikasikan kesimpulan akhir. Pada tahap mengecek kembali hasil pemecahan masalah kedua subjek FD tidak dapat melakukan pengecekan kembali terhadap hasil pekerjaannya dan tidak dapat membuat alternatif jawaban lain.

\section{DAFTAR PUSTAKA}

Agoestanto, A., \& Sukestiyarno, Y. L. (2017). Analysis of Mathematics Critical Thinking Students in Junior High School Based on Cognitive Style. In Journal of Physics: Conference Series (Vol. 824, No. 1, p. 012052). IOP Publishing.

Ari, A. A., \& Katrancl, Y. (2014). The opinions of primary mathematics student-teachers on problembased learning method. Procedia-Social and Behavioral Sciences, 116, 1826-1831.

Davidson, N., \& Major, C. H. (2014). Boundary crossings: Cooperative learning, collaborative learning, and problem-based learning. Journal on excellence in college teaching, 25.

Häkkinen, P., Järvelä, S., Mäkitalo-Siegl, K., Ahonen, A., Näykki, P., \& Valtonen, T. (2017). Preparing teacher-students for twenty-first-century learning practices (PREP 21): a framework for enhancing collaborative problem-solving and strategic learning skills. Teachers and Teaching, 23(1), 2541.

Jaisook, S., Chidmongkol, S., \& Thongthew, S. (2013). the Development of Instructional Model By Integrating Problem-Based Learning and Collaborative Learning Approach To Enhance Mathematical Problem Solving, Communication and Connection Abilities. 7th International Technology, Education and Development Conference, 13(2), 3196-3204.

Karaçam, S., \& Digilli Baran, A. (2015). The effects of field dependent/field independent cognitive styles and motivational styles on students' conceptual understanding about direct current circuits. Asia-Pacific Forum on Science Learning and Teaching, 16(2), 1-19.

Karatas, I., \& Baki, A. (2017). The effect of learning environments based on problem solving on students' achievements of problem solving. International Electronic Journal of Elementary Education, 5(3), 249-268.

Mulyati, T. (2016). Kemampuan Pemecahan Masalah Matematis Siswa Sekolah Dasar. EduHumaniora | Jurnal Pendidikan Dasar Kampus Cibiru, 3(2), $143-148$.

Murray-harvey, R., Pourshafie, T., \& Reyes, W. S. (2013). What teacher education students learn about collaboration from problem-based learning. 
Journal of Problem Based Learning in Higher Education, 1(1), 114-134.

Riset, P. M. (2015). Teknologi, dan Pendidikan Tinggi (PERMEN RISTEKDIKTI) Republik Indonesia Nomor 44 Tahun 2015 Standar Nasional Pendidikan Tinggi. 21 Desember 2015. Berita Negara Republik Indonesia Tahun.

Pólya, G., \& Conway, J. H. (1910). How to solve it: A new aspect of mathematical method. Princeton, NJ: Princeton University Press.

Prabawa, E. A., \& Zaenuri, Z. (2017). Analisis Kemampuan Pemecahan Masalah Ditinjau Dari Gaya Kognitif Siswa Pada Model Project Based Learning Bernuansa Etnomatematika. Unnes Journal of Mathematics Education Research, 6(1), 120129.

Servant-Miklos, V. F. (2019). The Harvard Connection: How the Case Method Spawned Problem-Based Learning at McMaster University. Health Professions Education, 5(3), 163-171.

Susanto, H. (2013). Pemahaman Mahasiswa Dalam Pemecahan Masalah Pembuktian Pada Konsep Grup Berdasarkan Gaya Kognitif. Jurnal Pendidikan Dan Pembelajaran Universitas Negeri Malang, 20(2), 124-133.

Tiffany, F., Surya, E., Panjaitan, A., \& Syahputra, E. (2017). Analysis Mathematical Communication Skills Student At the Grade. Ijariie-Issn(O)-2395-4396, 3(2), 2160-2164.

Tiwari, A., Lai, P., So, M., \& Yuen, K. (2006). A compari- son of the effects of problem-based learning and lecturing on the development of students' critical thinking. Medical education, 40(6), 547-554.

Ulya, H. (2015). Hubungan gaya kognitif dengan kemampuan pemecahan masalah matematika siswa. Jurnal Konseling GUSJIGANG, 1(2).

Ulya, H.; Kartono; and Retnoningsih, A.R. (2014). Analysis of Mathematics Problem Solving Ability of Junior High School Students Viewed from Students Cognitive Style. Prosiding ICMSE UNNES, pp. M1-M7.

Vega-Vaca, M., \& Hederich-Martnez, C. (2015). The impact of a cooperative learning program on the academic achievement in mathematics and language in fourth grade students and its relation to cognitive style. Journal of New Approaches in Educational Research (NAER Journal), 4(2), 84-90.

Widyatiningtyas, R., Kusumah, Y. S., Sumarmo, U., \& Sabandar, J. (2015). The Impact of Problem-Based Learning Approach to Senior High School Students' Mathematics Critical Thinking Ability. Indonesian Mathematical Society Journal on Mathematics Education, 6(2), 30-38.

Winarso, W., \& Dewi, W. Y. (2017). Berpikir kritis siswa ditinjau dari gaya kognitif visualizer dan verbalizer dalam menyelesaikan masalah geometri. Beta: Jurnal Tadris Matematika, 10(2), 117-133.

Yousefi, M. (2011). Cognitive style and EFL learners' listening comprehension ability. Indonesian journal of applied linguistics, 1(1), 73-83. 